\title{
Drug concentrations in the serum and cerebrospinal fluid of patients treated with norvancomycin after craniotomy
}

\author{
Y. Wu ${ }^{1} \cdot$ J. Kang $^{2} \cdot$ Q. Wang $^{3}$
}

Received: 9 August 2016/Accepted: 23 September 2016/Published online: 13 October 2016

(C) The Author(s) 2016. This article is published with open access at Springerlink.com

\begin{abstract}
Intracranial infection by gram-positive cocci is commonly found after craniotomy. Norvancomycin was independently developed in China, and had demonstrated therapeutic capability against gram-positive infection. This study investigated the serum and cerebrospinal fluid (CSF) concentrations in patients that received intravenous injection of norvancomycin after craniotomy. Patients with an indwelling catheter in the operational area/ventricle after craniotomy were administered norvancomycin by two approaches: (1) The conventional group consisted of 14 cases that were infused with $0.8 \mathrm{~g}$ norvancomycin for $1 \mathrm{~h}$, every $12 \mathrm{~h}$; (2) The continuous administration group consisted of 14 cases that were infused with $0.8 \mathrm{~g}$ norvancomycin for $1 \mathrm{~h}$, and then another $0.4 \mathrm{~g}$ for $11 \mathrm{~h}$ with extended infusion, followed by continuous infusion of $0.4 \mathrm{~g}$ norvancomycin for $12 \mathrm{~h}$. Samples of serum and CSF were collected at different time-points to measure norvancomycin levels after administration. In the conventional and continuous administration groups, the peak serum concentrations of norvancomycin were $55.52 \pm 26.04$ and $59.22 \pm 41.88 \mathrm{mg} / \mathrm{L}$, respectively, while those at $24 \mathrm{~h}$ were $8.21 \pm 6.04$ and $8.01 \pm 4.17 \mathrm{mg} / \mathrm{L}$, respectively. Meanwhile, peak CSF concentrations were $16.31 \pm 11.15$ and $8.82 \pm$ $8.91 \mathrm{mg} / \mathrm{L}$, respectively, while those at $24 \mathrm{~h}$ were $6.12 \pm$
\end{abstract}

Q. Wang

ttyywq@163.com

1 Respiratory and Critical Care Medicine, Beijing Anzhen Hospital, Capital Medical University, Beijing 100029, People's Republic of China

2 Department of Neurosurgery, Affiliated Cancer Hospital of Zhengzhou University, Zhengzhou 450008, People's Republic of China

3 Intensive Care Unit, Beijing Tiantan Hospital, Capital Medical University, Beijing 100050, People's Republic of China
2.34 and $6.24 \pm 4.38 \mathrm{mg} / \mathrm{L}$, respectively. This preliminary study showed that for the early administration of standard doses of norvancomycin post-neurosurgery, the CSF concentration in both the conventional and continuous administration groups reached or exceeded the $90 \%$ minimum inhibitory concentration $\left(\mathrm{MIC}_{90}, 2 \mathrm{mg} / \mathrm{L}\right)$ of target bacteria such as methicillin-resistant Staphylococcus aureus (MRSA).

\section{Background}

Intracranial infection after craniotomy, one of the most severe postoperative complications, is a challenge in neurosurgical treatment. Its high incidence impacts outcomes of patients dramatically $[1,2]$. The leading pathogens of surgical site infections in postneurosurgical patients are Gram-positive bacteria, especially S. aureus. Epidemiological studies of nosocomial infection in our unit revealed that gram-positive bacteria were still common pathogens among intracranial infections after craniotomy, which mainly included methicillinresistant coagulase negative staphylococci (MRCoNS) and Staphylococcus aureus [3, 4].

Vancomycin is a glycopeptides antibiotic that has been widely used with activity primarily directed toward Grampositive pathogens, such as Staphylococcus aureus, methicillin-resistant Staphylococcus aureus, Staphylococcus epidermis, and Enterococcus faecalis [5, 6]. Therefore, Vancomycin currently is commonly used as a first-line empiric antibiotic therapy to prevent and treat these intracranial infections [6,7], despite its low CSF permeability.

Norvancomycin, a glycopeptide antimicrobial agent, was independently developed by Chinese scientists, with a comparable antibacterial spectrum and antibacterial activities to those of vancomycin [8]. Norvancomycin had been widely used in neurosurgery in China, although pharmacokinetics- 
related studies conducted with this antimicrobial after craniotomy have been rarely reported. Our studies preliminarily confirmed that damage of the blood-brain barrier (BBB) by neurosurgery was likely to increase the concentrations of vancomycin and other antibiotics in the CSF of post-operative patients [9, 10].

This study was designed to investigate whether there is an increased CSF penetration of norvancomycin into the cerebrospinal fluid increases after $\mathrm{BBB}$ is impaired following craniotomy, and whether continuous infusion time affects drug concentration.

\section{Study design}

This was a prospective observational study.

\section{Materials and methods}

\section{Patients}

The study was approved by the Research Ethics Committee in Tiantan Hospital, Capital Medical University (Beijing, China,KY2014-014-02, June 4, 2014). Written informed consent was obtained from all patients or their healthcare surrogates prior to enrollment in the study.

\section{Inclusion criteria}

Criteria for inclusion were neurosurgical patients (18-70 years old, entering the ICU of Beijing Tiantan Hospital) with an indwelling ventricular drainage pipe after neurological surgery who were treated with norvancomycin for prevention of intracranial infection between June and October in 2014.

\section{Exclusion criteria}

Criteria for exclusion were patients that had a history of vancomycin or norvancomycin allergies; patients that had received antibiotics against gram-positive bacteria such as MRSA within 7 days before enrollment; patients that were in an agonal state, deep coma, absence of spontaneous breathing, or that had suffered from severe dysfunction of the heart, lung, liver, kidney or other organs; pregnant women in a perinatal stage; and patients that had to combine drug therapy, which might increase drug toxicity, including aminoglycosides, salicylates and blood-lipid regulation drugs, among others.

\section{Administration norvancomycin and specimen collection}

We maintained continuous observation of 14 patients with conformance to the conventional drug administration, and continuous observation of 14 cases of giving continuous dosing. Norvancomycin solution was formulated using norvancomycin (North China Pharmaceutical Group Corporation, China, $400 \mathrm{mg} /$ bottle) and $0.9 \%$ normal saline. Patients in the conventional group were infused with $0.8 \mathrm{~g}$ norvancomycin for $1 \mathrm{~h}$ every $12 \mathrm{~h}$. In addition, the continuous administration group consisted of 14 cases that were administrated with $0.8 \mathrm{~g}$ norvancomycin for $1 \mathrm{~h}$, with an extended infusion of $0.4 \mathrm{~g}$ for $11 \mathrm{~h}$, followed by continuous infusion of $0.4 \mathrm{~g}$ for $12 \mathrm{~h}$.

Venous blood and CSF were sampled from both groups at the following time points after administration. For the conventional group, $1-1.5 \mathrm{ml} \mathrm{CSF}$ and $2-2.5 \mathrm{ml}$ blood sample specimens were drawn at $1 \mathrm{~h}$ following the start of an infusion of norvancomycin (ending) for 2, 3, 4, 6, 12, 13, 14 and $24 \mathrm{~h}$. For the continuous administration group, samples were drawn at $1 \mathrm{~h}$ after administration (ending), and at 2, 3, 4, 6, 12 and $24 \mathrm{~h}$, following which, samples were rapidly centrifuged at 3 $500 \mathrm{rpm}$ for $3 \mathrm{~min}$, where the supernatant was stored frozen at $-20{ }^{\circ} \mathrm{C}$ and transferred to the pharmacology laboratory of the hospital as soon as possible, and then stored in a $-70{ }^{\circ} \mathrm{C}$ freezer and ultimately transferred to the central laboratory of the Capital Medical University for uniform testing.

\section{Determination of norvancomycin concentration}

\section{Drugs and agents}

We used standard vancomycin (i.e., as obtained from The National Institute for the Control of Pharmaceutical and Biological Products; batch number: 0360-200301, and equivalent in dose to $1,007 \mathrm{U} / \mathrm{mg}$ ), standard norvancomycin (The National Institute for the Control of Pharmaceutical and Biological Products; batch number: 130338-200303, and equivalent to $914 \mathrm{U} / \mathrm{mg}$, content $83.4 \%$ ), acetonitrile (Fisher-Scientific, USA, chromatographic pure grade), and analytical reagents, including potassium dihydrogen phosphate $\left(\mathrm{KH}_{2} \mathrm{PO}_{4}\right)$, phosphate, perchloric acid and dichloromethane and deionized water (Millipore Direct+Q).

\section{Instruments}

We used high performance liquid chromatography (HPLC; Waters, USA) using a 1525 high-pressure infusion system, 717 sampling system, equipped with a 2487 ultraviolet detector and a Waters Breeze chromatographic work station. We also used an Eppendorf high-speed centrifuge, a Stuart turbine mixer, and a Millipore Direct+Q pure-water system (Millipore Ltd., United States). 


\section{Experimental methods}

\section{Chromatographic conditions}

The chromatographic column used was a Sapax C18 column, USA $(250 \times 4.6 \mathrm{~mm}, 5 \mu \mathrm{m})$; the mobile phase was acetonitrile $0.05 \mathrm{~mol} / \mathrm{L} \mathrm{KH} 2 \mathrm{PO} 4$ buffer $(\mathrm{pH}=3.3)$ at a ratio of $10: 90$, with a measured wavelength of $230 \mathrm{~nm}$, a velocity of $1.0 \mathrm{ml} / \mathrm{min}$, a column temperature of $30^{\circ} \mathrm{C}$, and a sample volume of $10 \mu \mathrm{l}$.

\section{Preparation of control solution}

For this preparation, $0.0164 \mathrm{~g}$ standard norvancomycin was accurately weighed and placed into a $25 \mathrm{ml}$ volumetric flask, dissolved in purified water to a final concentration of $657.3 \mathrm{mg} / \mathrm{L}$ control solution, which was double diluted to obtain serial stock solutions at concentrations of 328, 164, $80,40,20$ and $10 \mu \mathrm{g} / \mathrm{ml}$. Then, $0.0184 \mathrm{~g}$ vancomycin was accurately weighed and placed into a $25 \mathrm{ml}$ volumetric flask, and then dissolved in purified water to obtain a $736.0 \mathrm{mg} / \mathrm{ml}$ internal stock solution.

\section{Management of plasma/cerebrospinal fluid specimens}

In these studies, $0.5 \mathrm{ml}$ plasma/cerebrospinal fluid was placed into a test-tube, each of which had $60 \mu \mathrm{l}$ of distilled water, $30 \mu \mathrm{l}$ of an internal stock solution, and $170 \mu 110 \%$ perchloric acid added. Then specimens were vortexed for $40 \mathrm{~s}$ and centrifuged at $4000 \mathrm{rpm}$ for $10 \mathrm{~min}$, from which the supernatant was collected and $800 \mu \mathrm{l}$ dichloromethane was added. This was then vortexed for $1 \mathrm{~min}$ and centrifuged at $4000 \mathrm{rpm}$ for $10 \mathrm{~min}$, from which the supernatant was collected for sampling.

\section{Preparation of standard curves}

In these studies, $0.5 \mathrm{ml}$ of plasma/cerebrospinal fluid specimens was accurately drawn into a test tube, each of which was tested against the formulated serial stock solution of norvancomycin to obtain norvancomycin mass concentrations of $131.46,65.73,32.87,16.43,8.22,4.11$ and $2.05 \mu \mathrm{g} / \mathrm{ml}$, following which, the above mentioned management was applied to each test-tube, followed by testing according to preset chromatographic conditions. The peak areas of the norvancomycin and internal label were recorded, and then regression analyses were performed using the weighted least squares method by taking the ratio of the peak area of norvancomycin over that of vancomycin as the horizontal $(\mathrm{X})$ axis, and the mass concentration of norvancomycin as the longitudinal $(\mathrm{Y})$ axis, thereby obtaining the regression equation of the plasma as follows:

$\mathrm{Y}_{1}=22.896 \mathrm{X}_{1}+1.559, \mathrm{r}_{1}=0.9994$
Wherein the linear range of norvancomycin in the plasma was $2.05-131.46 \mu \mathrm{g} / \mathrm{ml}$ and the lower limit of detection was quantified as $2.05 \mu \mathrm{g} / \mathrm{ml}$. The regression equation of CSF specimens was as follows:

$\mathrm{Y}_{2}=51.192 \mathrm{X}_{2}-6.533, \mathrm{r}_{2}=0.996$

Wherein the linear range of norvancomycin in CSF was $2.05-131.46 \mu \mathrm{g} / \mathrm{ml}$ and the lower limit of detection was quantified as $2.05 \mu \mathrm{g} / \mathrm{ml}$.

\section{Statistical analyses}

All the data were analyzed by Microsoft Office Excel 2013. The norvancomycin concentrations in the serum and CSF specimens at each time point were calculated, and the data were expressed as mean \pm standard deviation $(\bar{x} \pm \mathrm{SD})$. The concentration-time curves were drawn by taking the time as the horizontal axis and the norvancomycin concentration as the longitudinal axis. In addition, the ratios of the area under the serum concentration curve over the $\mathrm{MIC}_{90}$ of MRSA were calculated, with the intention of comparing the relationships of norvancomycin concentrations in both serum and CSF specimens with the corresponding bacterial $\mathrm{MIC}_{90}$ at each time-point, where the CSF permeability of the norvancomycin was described using the ratio of CSF and serum concentration peaks as well as the ratio of the areas under the curve.

\section{Results}

Twenty-eight patients were enrolled in the study, of which the conventional group consisted of ten male and four female study subjects with a mean age of $40 \pm 17$ years and a mean weight of $73 \pm 13 \mathrm{~kg}$. Meanwhile the continuous administration group consisted of 11 males and three females, with a mean age of $47 \pm 14$ years and a mean weight of $75 \pm 10 \mathrm{~kg}$. Drugs that might increase drug toxicity including aminoglycosides, salicylates and blood-lipid regulatory drugs were not given to any of the patients during administration. Basic information and clinical chemistry measurements are listed in Tables 1, 2, and 3 .

In the conventional group, serum levels of norvancomycin peaked with a value of $55.52 \pm 26.04 \mathrm{mg} / \mathrm{L}$ at $1 \mathrm{~h}$ after infusion, which decreased to $10.62 \pm 10.33$ and $8.21 \pm 6.04 \mathrm{mg} / \mathrm{L}$ by 12 and $24 \mathrm{~h}$, respectively. By contrast, levels of norvancomycin in the CSF peaked with a value of $16.31 \pm$ $11.15 \mathrm{mg} / \mathrm{L}$ by $3 \mathrm{~h}$ after administration, which decreased to $8.32 \pm 5.16$ and $6.12 \pm 2.34 \mathrm{mg} / \mathrm{L}$ by 12 and $24 \mathrm{~h}$, respectively.

Meanwhile, in the continuous administration group, serum levels of norvancomycin peaked with a value of 59.22 $\pm 41.88 \mathrm{mg} / \mathrm{L}$ at $1 \mathrm{~h}$ after infusion, which decreased to 8.27 \pm 5.75 and $8.01 \pm 4.17 \mathrm{mg} / \mathrm{L}$ by 12 and $24 \mathrm{~h}$, respectively. By 
Table 1 Patient characteristics in conventional groups

\begin{tabular}{|c|c|c|c|}
\hline Case & Diagnosis & $\begin{array}{l}\text { Drainage tube } \\
\text { position }\end{array}$ & Antibiotics before administration \\
\hline 1 & Central neurocytoma of left ventricle & Ventricles & Intraoperative $2 \mathrm{~g}$ ceferiaxone $\mathrm{e}^{\mathrm{a}}$ \\
\hline 2 & Glioblastomas of right forehead & $\begin{array}{l}\text { Operational cavity } \\
\text { drainage }\end{array}$ & $\begin{array}{l}\text { Piperacillin sodium and Sulbactam } \\
\text { sodium: } 5 \mathrm{gQ} 8 \mathrm{~h}\end{array}$ \\
\hline 3 & Right frontotemporal glioma & $\begin{array}{l}\text { Operational cavity } \\
\text { drainage }\end{array}$ & Intraoperative $1.5 \mathrm{~g}$ cefuroxime \\
\hline 4 & Meningioma of left petrosal apex & Subdural drainage & Intraoperative $2 \mathrm{~g}$ ceferiaxone \\
\hline 5 & Meningioma of left ventricle & $\begin{array}{l}\text { Operational cavity } \\
\text { drainage }\end{array}$ & Intraoperative $1 \mathrm{~g}$ ceferiaxone \\
\hline 6 & Left cerebral arteriovenous malformation & Hematoma cavity & Ceftazidine: 2gQ8h \\
\hline 7 & $\begin{array}{l}\text { Bleeding of cerebellar glioma, } \\
\text { ventriculopuncture drainage }\end{array}$ & Ventricles & Intraoperative $2 \mathrm{~g}$ ceferiaxone \\
\hline 8 & Right frontal clear cell carcinoma & $\begin{array}{l}\text { Operational cavity } \\
\text { drainage }\end{array}$ & Intraoperative $2 \mathrm{~g}$ cefuroxime \\
\hline 9 & Right frontotemporal glioma & $\begin{array}{l}\text { Operational cavity } \\
\text { drainage }\end{array}$ & Intraoperative $1.5 \mathrm{~g}$ cefuroxime \\
\hline 10 & $\begin{array}{l}\text { Fracture of left cerebral artery } \\
\text { aneurysm,SAH }\end{array}$ & Ventricles & Ceftazidine: $2 \mathrm{gQ} 8 \mathrm{~h}$ \\
\hline 11 & Left petroclival meningioma & $\begin{array}{l}\text { Operational cavity } \\
\text { drainage }\end{array}$ & Ceftazidine: $2 \mathrm{gQ} 8 \mathrm{~h}$ \\
\hline 12 & Petroclival meningioma & $\begin{array}{l}\text { Operational cavity } \\
\text { drainage }\end{array}$ & Sulperazone: $1.5 \mathrm{gQ} 6 \mathrm{~h}$ \\
\hline 13 & Central neurocytoma & $\begin{array}{l}\text { Operational cavity } \\
\text { drainage }\end{array}$ & \\
\hline 14 & Astrocytoma of thalamus and midbrain & Ventricles & Ceftazidine: $2 \mathrm{gQ} 8 \mathrm{~h}$ \\
\hline
\end{tabular}

${ }^{a}$ Well as cerebrospinal fluid penetration rate, ceftriaxone, widely used in China
Table 2 Patient characteristics in continuous groups

\begin{tabular}{|c|c|c|c|}
\hline Case & Diagnosis & Drainage tube position & Antibiotics before administration \\
\hline 1 & Glioma in corpus callosum & $\begin{array}{l}\text { Operational cavity } \\
\text { drainage }\end{array}$ & Intraoperative $3 \mathrm{~g}$ cefuroxime \\
\hline 2 & Parasellar meningioma & Ventricles & Intraoperative $1 \mathrm{~g}$ ceferiaxone \\
\hline 3 & $\begin{array}{l}\text { Pineal tumor of corpus } \\
\text { callosum }\end{array}$ & $\begin{array}{l}\text { Operational cavity } \\
\text { drainage }\end{array}$ & Intraoperative $2 \mathrm{~g}$ ceferiaxone \\
\hline 4 & $\begin{array}{l}\text { Central neurocytoma of right } \\
\text { ventricle }\end{array}$ & Ventricles & Intraoperative $1 \mathrm{~g}$ ceferiaxone \\
\hline 5 & Craniopharyngioma & $\begin{array}{l}\text { Operational cavity } \\
\text { drainage }\end{array}$ & Intraoperative $1.5 \mathrm{~g}$ cefuroxime \\
\hline 6 & $\begin{array}{l}\text { Neurilemmoma of left petrosal } \\
\text { apex }\end{array}$ & $\begin{array}{l}\text { Operational cavity } \\
\text { drainage }\end{array}$ & $\begin{array}{l}\text { Piperacillin sodium and Sulbactam } \\
\text { sodium: } 5 \mathrm{gQ} 8 \mathrm{~h}\end{array}$ \\
\hline 7 & Glioma of left tempus sinistrum & $\begin{array}{l}\text { Operational cavity } \\
\text { drainage }\end{array}$ & Ceftazidine: $2 \mathrm{gQ} 8 \mathrm{~h}$ \\
\hline 8 & Neurilemmoma of left CPA & $\begin{array}{l}\text { Operational cavity } \\
\text { drainage }\end{array}$ & - \\
\hline 9 & Craniopharyngioma & $\begin{array}{l}\text { Operational cavity } \\
\text { drainage }\end{array}$ & Intraoperative $1.5 \mathrm{~g}$ cefuroxime \\
\hline 10 & Right frontal astrocytoma & Subdural drainage & - \\
\hline 11 & Glioma of right thalamus & Ventricles & Ceftazidine: $2 \mathrm{gQ} 8 \mathrm{~h}$ \\
\hline 12 & Craniopharynglioma & $\begin{array}{l}\text { Operational cavity } \\
\text { drainage }\end{array}$ & - \\
\hline 13 & Deutocerebral glioma & $\begin{array}{l}\text { Operational cavity } \\
\text { drainage }\end{array}$ & \\
\hline 14 & Cerebellar meningioma & $\begin{array}{l}\text { Operational cavity } \\
\text { drainage }\end{array}$ & - \\
\hline
\end{tabular}


Table 3 Patient characteristics in two groups

\begin{tabular}{llll}
\hline Characteristics & Conventional $(N=14)$ & Continuous $(N=14)$ & $P$ value \\
\hline Age, years & $40 \pm 17$ & $47 \pm 14$ & 0.264 \\
Gender, $\%$ male & $71.4(10 / 14)$ & $78.6(11 / 14)$ & 1.000 \\
Weight, $\mathrm{kg}$ & $72.9 \pm 12.6$ & $75.4 \pm 9.9$ & 0.564 \\
Creatinine, $\mu \mathrm{g} / \mathrm{ml}$ & $51.6 \pm 12.6$ & $53.8 \pm 17.1$ & 0.709 \\
Day after neurosurgery $^{\mathrm{a}}$ & $1.3 \pm 0.5$ & $1.5 \pm 1.1$ & 0.596 \\
\hline
\end{tabular}

${ }^{\text {a }}$ One day represented the same day after neurosurgery contrast, the levels in the CSF peaked with a value of $8.82 \pm$ $8.91 \mathrm{mg} / \mathrm{L}$ by $4 \mathrm{~h}$ after administration, which decreased to $3.28 \pm 1.64$ and $6.24 \pm 4.39 \mathrm{mg} / \mathrm{L}$ by 12 and $24 \mathrm{~h}$, respectively.

In the conventional group, penetration of the CSF by the drug that was obtained using the ratios of the peak concentrations during the periods of $1-12$ and 12-24 $\mathrm{h}$ were 29.4 and $16.7 \%$, respectively. By contrast, in the continuous administration group, the CSF penetration by the drug that was obtained by using the ratio of the peak concentration and the ratio of the areas under the curves during the 1-12 and 12$24 \mathrm{~h}$ were 14.9 and $34.3 \%$, respectively. In addition, taking the $\mathrm{MIC}_{90}$ of the target bacteria like MRSA as $2 \mathrm{mg} / \mathrm{L}$ [6], the areas under the serum concentration-time curve $\mathrm{AUC}_{0-24} /$ $\mathrm{MIC}_{90}$ were 193 and 181 in the conventional and continuous administration groups, respectively. The drug concentrations at various time-points are shown in Tables 4 and 5, and Figs. 1 and 2, which illustrate the concentration-time curves of the norvancomycin in both groups.

\section{Discussion}

Although vancomycin does not penetrate the BBB with high permeability, it is currently still a standard antibiotic protocol for treating intracranial infection caused by MRSA and MRCoNS after craniotomy. Norvancomycin has been considered to have a comparable antibacterial spectrum and anti-bacterial activity to those described for vancomycin. It had been widely used in preventing and treating gram-positive infection in China, although is not available therapeutically outside of China and pharmacokinetics-related studies conducted with this antimicrobial are rarely reported [11], especially the permeability of norvancomycin through the BBB in neurosurgery patients.

It has been previously found that damage to the BBB caused by neurosurgery tended to increase the vancomycin concentration in the CSF in the early stages after craniotomy, and intravenous infusion following a normal dose of $1 \mathrm{~g}$ for $1 \mathrm{~h}$ showed a peak CSF concentration of $6.24 \pm 3.46 \mathrm{mg} / \mathrm{L}$ and a nadir of $2.55 \pm 1.13 \mathrm{mg} / \mathrm{L}$, which tended to achieve and exceed the $2 \mathrm{mg} / \mathrm{L} \mathrm{MIC}_{90}$ of target bacterial MRSA [12].

In this study, we applied a normal daily dose of $1.6 \mathrm{~g}$ norvancomycin in a similar population in the early stages post-neurosurgery, and the results showed that in both the conventional and continuous administration groups, the CSF peak and trough concentrations were likely to exceed those of vancomycin. However, whether the BBB permeability of norvancomycin was higher than that of vancomycin warranted further investigation.

Referring to the literature [13-17], the $\mathrm{MIC}_{90}$ of norvancomycin to MRSA and MRCoNS were 0.5-2 and 1$4 \mathrm{mg} / \mathrm{L}$, respectively, while that to Staphylococcus epidermidis could be as high as $4 \mathrm{mg} / \mathrm{L}$. Thus, this study revealed that applying a normal dose of norvancomycin in the early stages post-neurosurgery tended to obtain an

Table 4 Drug concentrations in the serum and CSF of the conventional group

\begin{tabular}{lll}
\hline Time (hours) & \multicolumn{2}{l}{ Norvancomycin $(\mathrm{x} \pm \mathrm{SD})(\mathrm{n})(\mathrm{range})$} \\
\cline { 2 - 3 } & Serum & Cerebrospinal fluid \\
\hline Prior to administration & 0 & 0 \\
1 & $55.52 \pm 26.04(8)$ & $15.78 \pm 8.63(7)$ \\
& $(8.79-91.84)$ & $(4.03-27.05)$ \\
2 & $33.33 \pm 23.52(11)$ & $16.14 \pm 9.57(11)$ \\
& $(6.07-67.21)$ & $(3.03-26.34)$ \\
3 & $22.35 \pm 20.37(10)$ & $16.31 \pm 11.15(9)$ \\
& $(3.38-59.13)$ & $(3.48-37.95)$ \\
4 & $15.68 \pm 14.77(5)$ & $15.18 \pm 16.88(6)$ \\
& $(3.44-39.65)$ & $(3.37-48.66)$ \\
6 & $12.07 \pm 7.50(5)$ & $10.00 \pm 7.88(4)$ \\
& $(6.10-24.99)$ & $(2.80-21.21)$ \\
12 & $10.62 \pm 10.33(10)$ & $8.32 \pm 5.16(12)$ \\
& $(2.15-36.88)$ & $(2.68-19.75)$ \\
13 & $49.73 \pm 35.31(5)$ & $7.62 \pm 3.78(3)$ \\
& $(4.77-102.48)$ & $(4.49-11.81)$ \\
14 & $17.22 \pm 6.52(3)$ & $8.32 \pm 6.34(3)$ \\
& $(11.93-24.50)$ & $(3.19-15.41)$ \\
24 & $8.21 \pm 6.04(5)$ & $6.12 \pm 2.34(5)$ \\
& $(2.10-17.13)$ & $(3.15-9.24)$ \\
\hline
\end{tabular}


Table 5 Drug levels in the serum and CSF of the continuous administration group

\begin{tabular}{lll}
\hline Time (hours) & \multicolumn{2}{l}{ Norvancomycin $(\mathrm{x} \pm \mathrm{SD})(\mathrm{n})($ range $)$} \\
\cline { 2 - 3 } & Serum & Cerebrospinal fluid \\
\hline Prior to administration & 0 & 0 \\
1 & $59.22 \pm 41.88(10)$ & $7.49 \pm 3.62(9)$ \\
& $(26.96-160.59)$ & $(2.50-12.37)$ \\
2 & $42.13 \pm 30.11(9)$ & $8.62 \pm 3.71(9)$ \\
& $(7.80-108.90)$ & $(3.41-13.56)$ \\
3 & $30.11 \pm 18.75(10)$ & $7.17 \pm 2.91(7)$ \\
& $(7.08-72.41)$ & $(3.41-9.88)$ \\
4 & $26.45 \pm 17.10(10)$ & $8.82 \pm 8.91(8)$ \\
& $(4.86-65.53)$ & $(2.92-30.43)$ \\
6 & $17.18 \pm 10.08(9)$ & $5.19 \pm 3.26(10)$ \\
& $(3.92-38.01)$ & $(2.85-9.09)$ \\
12 & $8.27 \pm 5.75(12)$ & $3.28 \pm 1.64(11)$ \\
& $(2.72-18.87)$ & $(0.21-6.51)$ \\
24 & $8.01 \pm 4.17(5)$ & $6.24 \pm 4.38(4)$ \\
& $(2.28-15.68)$ & $(2.33-12.54)$ \\
\hline
\end{tabular}

effective concentration to the above target bacteria in CSF by both conventional and continuous administration groups. However, the drug concentration in the CSF tended to present a decreasing trend with time, which might indicate that the permeability of the drug had declined with gradual repair of the BBB. Further studies are needed to investigate the temporal durability of the damage to the BBB and how long a higher concentration of norvancomycin will be retained in CSF.

Also, a significant advantage of continuous administration was not observed, which needs further investigation. In addition, this study adopted a normal dose $(1.6 \mathrm{~g} / \mathrm{d})$ of norvancomycin, which showed that an effective concentration could be obtained in CSF in the early stages after craniotomy. Previous results showed that the recommended dose of vancomycin should be gradually increased in treating intracranial

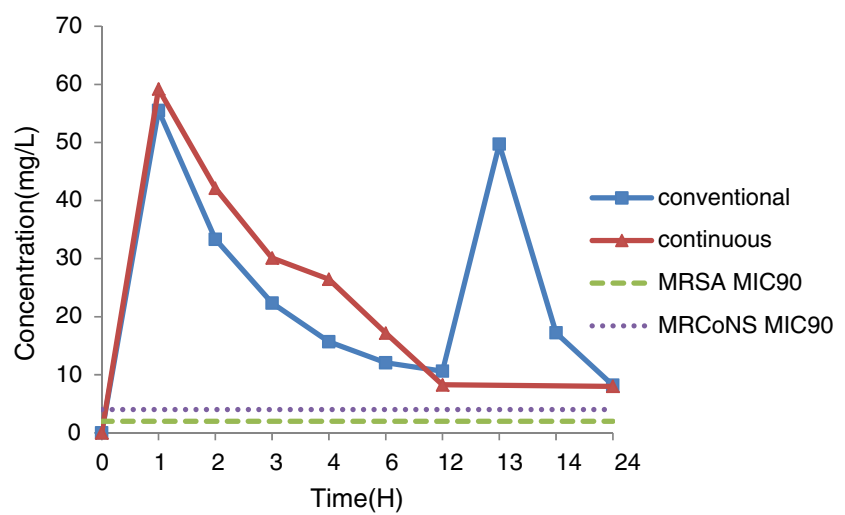

Fig. 1 Serum concentration-time curve of norvancomycin in the conventional and continuous group

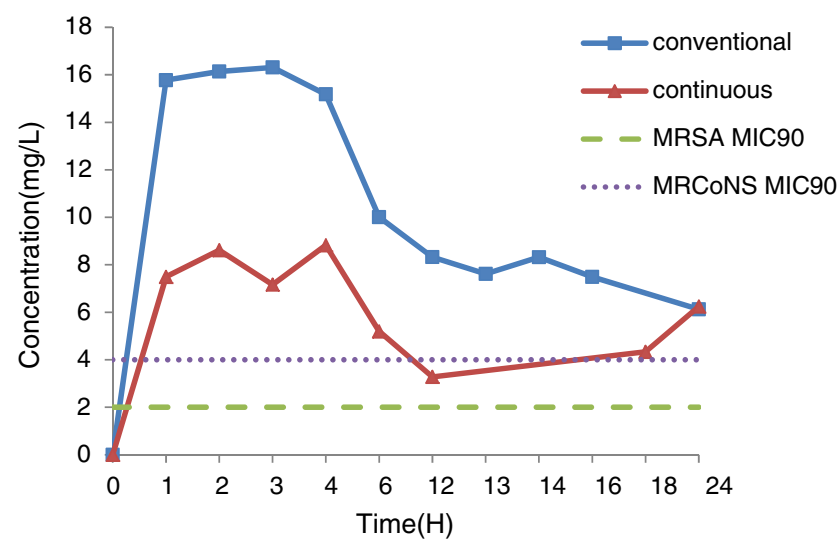

Fig. 2 CSF concentration-time curve of norvancomycin in the conventional and continuous group

infection because of the "MIC shift" [18]. This is caused by gradual repair of the BBB and deteriorating drug resistance. However, whether it is necessary and safe to increase the dose of norvancomycin in treating intracranial infection requires further study.

In this study, a relative large standard deviation of drug concentration was obtained, which might be associated with the errors caused by deviation of sampling time, transportation, storage and detection of the specimens as well as a relatively small sample size. However, more importantly, it might have been due to a failure to administer a dose according to body weight since the degree of BBB permeability might differ in different patients. Therefore, studies with improved quality control and a larger sample size are expected.

In summary, this study preliminarily investigated the serum concentrations and CSF permeability with different administration methods of norvancomycin. These studies also provided preliminary clinical pharmacological evidence for assessing its value in preventing intracranial infection after neurosurgery.

\section{Conclusions}

It indicated that the drug concentrations in the blood and CSF could obtain and exceed the $\mathrm{MIC}_{90}$ of the target bacteria, such as MRSA in both conventional and continuous administration groups, when applying a standard dose of norvancomycin in an early stage after neurosurgery. However, we failed to observe significant advantages of a continuous administration method over the conventional administration method. This study is a pilot research of norvancomycin used in neurosurgical individuals, which needs to be confirmed by further large-scale studies 
Acknowledgments I would like to show my deepest gratitude to my colleagues in ICU and department of neurosurgery in Tiantan Hospital. Without their enlightening instructions, impressive kindness and patience, I could not have completed my thesis.

Authors' contributions Y-XW and QW participated in design of the study and drafted the manuscript. J-LK participated in collecting the specimens and clinical data. Y-XW participated in statistical analysis. All authors edited the manuscript and read and approved the final manuscript.

\section{Compliance with ethical standards}

Funding None

Interests competing The authors declare that they have no competing interests.

Ethics approval Ethical approval was provided by the IRB of the Beijing Tiantan Hospital, Capital Medical University.

Open Access This article is distributed under the terms of the Creative Commons Attribution 4.0 International License (http:// creativecommons.org/licenses/by/4.0/), which permits unrestricted use, distribution, and reproduction in any medium, provided you give appropriate credit to the original author(s) and the source, provide a link to the Creative Commons license, and indicate if changes were made.

\section{References}

1. National Nosocomial Infections Surveillance System (2004) National Nosocomial Infections Surveillance (NNIS) system report, data summary from January 1992 through June 2004, issued October 2004. Am J Infect Control 32:470-485

2. Jin G-m, Dong Y-m, Yu A-r, Zhang Q-1 (2007) A meta-analysis of epidemiology of intracranial infection after craniotomy. Chin J Clin Neurosurg 12:149-151

3. Zhao L-h, Wang Q, Xv M, Tang M-z, Zhang Y, Zhou J-x (2009) Surveillance of bacterial resistance in neurosurgical ICU. Chin J Nosocomiol 19:2192-2194

4. Li Q, Wu Y-x, Tang M-Z, Wang Q (2015) Pathogenic bacteria distribution and resistance migration in cerebrospinal fluid of neurosurgical patients. Chinese Journal of Infection Control 14:159165

5. Martin JH, Norris R, Barras M, Roberts J, Morris R, Doogue M, Jones GR (2010) Therapeutic monitoring of vancomycin in adult patients: a consensus review of the American Society of HealthSystem Pharmacists, the Infectious Diseases Society of America, and the Society Of Infectious Diseases Pharmacists. Clin Biochem Rev 31:21-24

6. Rybak M, Lomaestro B, Rotschafer JC, Moellering R Jr, Craig W, Billeter M, Dalovisio JR, Levine DP (2009) Therapeutic monitoring of vancomycin in adult patients: a consensus review of the American Society of Health-System Pharmacists, the Infectious Diseases Society of America, and the Society of Infectious Diseases Pharmacists. Am J Health Syst Pharm 66:82-98

7. Tunkel AR, Hartman BJ, Kaplan SL, Kaufman BA, Roos KL, Scheld WM, Whitley RJ (2004) Practice guidelines for the management of bacterial meningitis. Clin Infect Dis 39:1267-1284

8. Dai Z-y, Liu Y-k, Wang F (1998) Practical antibacterial pharmaceutics $[\mathrm{M}]$ (Second edition). Shanghai Science and Technology Press, Shanghai, p 222-223

9. Wang Q, Wu Y-x, Chen B-y, Zhou J-x (2015) Drug concentrations in the serum and cerebrospinal fluid of patients treated with cefoperazone/sulbactam after craniotomy. BMC Anesthesiol 15: 33. doi:10.1186/s12871-015-0012-1

10. Wu Y-x, Chen G-q, Wang Q, Shi Z-h, Xv M, Chen K, Chen L, Lei Y-n, Huang J(2011) Study of concentration of vancomycin in serunl and CSF during continuous intravenous infusion. Chin J Neurosurg 27:73-76

11. Zhang J, Zhang Y, Shi Y, Rui J, Yu J, Cao G, Wu J (2008) Population pharmacokinetic and pharmacodynamic modeling of norvancomycin. Eur J Clin Microbiol Infect Dis 27:275-284

12. Wang Q, Shi Z, Wang J, Shi G, Wang S, Zhou J (2008) Postoperatively administered vancomycin reaches therapeutic concentration in the cerebral spinal fluid of neurosurgical patients. Surg Neurol 69:126-129

13. Zhang H, Xiao M, Yang QW, Wang Y, Wang H, Zhao Y, Brown M, Zhao HR, Kong F, Xu YC (2013) High ceftaroline nonsusceptibility in Staphylococcus aureus isolated from acute skin infections in 15 tertiary hospitals in China. J Med Microbiol 62: 496-497

14. Liang B-b, Wang R (2008) Antibacterial activities of linezolid, norvancomycin and other antibacterial drugs to methicillinresistant Staphylococcus aureus. Chin J Clin Pharmacol Therapeut 13:1044-1047

15. Li J-t, L Yun, Qi H-m (2005) Representative of China Bacterial resistance surveillance group.2002-2003 bacterial resistance surveillance on gram-positive cocci isolated from hospital and community acquired infections in China. Chin J Lab Med 28:254-265

16. Xiong Y-l, Fan X-j, Lv X-j, Feng P, Yu R-j, Kang M (2004) Resistance Analysis on Staphylococcus to 8 Antimicrobial Agents. Parasitoses Infect Dis 2:145-148

17. Li Z-x, Yang Y-c, Zhao J-h, Yang J-f, Shi D-y (2007) Observation of antibacterial activity of domestic vancomycin against 202 strains coagulase-negative staphylococcus(S.Epidermidis, S.Heamolyticus etc.) in vitro. J Hebei Med Univ 28:337-340

18. Chang W, Ma X, Gao P, Lv X, Lu H, Chen F (2015) Vancomycin MIC creep in methicillin-resistant Staphylococcus aureus (MRSA) isolates from 2006 to 2010 in a hospital in China. Indian J Med Microbiol 33:262-266 